Article

\title{
Impact of Fe and Ni Addition on the VFAs' Generation and Process Stability of Anaerobic Fermentation Containing Cd
}

\author{
Huayong Zhang *D, Yanli Xu, Yonglan Tian, Lei Zheng, He Hao and Hai Huang \\ Research Center for Engineering Ecology and Nonlinear Science, North China Electric Power University, \\ Beijing 102206, China; 17600754732@163.com (Y.X.); yonglantian@ncepu.edu.cn (Y.T.); \\ 15600462123@163.com (L.Z.); haohe333@126.com (H.H.); huanghai@ncepu.edu.cn (H.H.) \\ * Correspondence: rceens@ncepu.edu.cn; Tel.: +86-010-6177-3936
}

Received: 18 September 2019; Accepted: 19 October 2019; Published: 23 October 2019

check for updates

\begin{abstract}
The effects of $\mathrm{Cd}, \mathrm{Cd}+\mathrm{Fe}$, and $\mathrm{Cd}+\mathrm{Ni}$ on the thermophilic anaerobic fermentation of corn stover and cow manure were studied in pilot experiments by investigating the biogas properties, process stability, substrate biodegradation, and microbial properties. The results showed that the addition of $\mathrm{Fe}$ and $\mathrm{Ni}$ into the $\mathrm{Cd}$-containing fermentation system induced higher cumulative biogas yields and $\mathrm{NH}_{4}{ }^{+}-\mathrm{N}$ concentrations compared with the only $\mathrm{Cd}$-added group. $\mathrm{Ni}$ together with Cd improved and brought forward the peak daily biogas yields, and increased the $\mathrm{CH}_{4}$ contents to $80.76 \%$. Taking the whole fermentation process into consideration, the promoting impact of the $\mathrm{Cd}+\mathrm{Ni}$ group was mainly attributed to better process stability, a higher average $\mathrm{NH}_{4}{ }^{+}-\mathrm{N}$ concentration, and increased utilization of acetate. Adding Fe into the Cd-containing fermentation system increased the absolute abundance of Methanobrevibacter on the 13th day, and Methanobrevibacter and Methanobacterium were found to be positively correlated with the daily biogas yield. This research was expected to provide a basis for the reuse of biological wastes contaminated by heavy metals and a reference for further studies on the influence of compound heavy metals on anaerobic fermentation.
\end{abstract}

Keywords: compound heavy metals; anaerobic fermentation; biogas properties; process stability; substrate biodegradation; microbial properties

\section{Introduction}

Energy is the driving force for industrial development and global economic growth. In China, energy plays a key role in supporting one-fifth of the world's population and maintaining fast-growing gross domestic product (GDP) [1]. Similar to the case in a lot of other countries, fossil fuels are the main source of fuel for various forms of energy utilization in China [2]. However, fossil fuel resources are limited and will produce emissions of carbon dioxide $\left(\mathrm{CO}_{2}\right)$, nitrogen oxides $\left(\mathrm{NO}_{\mathrm{x}}\right)$, and other harmful gases in the process of utilization, which will cause environmental pollution and human health risks [1]. Consequentially, the world is looking for alternative, renewable, and sustainable energy sources [3]. Bioenergy is one of the most promising renewable clean energy options [4]. Biomass, including bioenergy plants, as a large, clean, and renewable energy, can effectively alleviate the energy shortage and reduce the emission of harmful gases [5].

Anaerobic fermentation, which uses biomass to produce biogas as clean energy, is an environmentally friendly and promising energy production technology [6]. The anaerobic fermentation process involves different types of microorganisms, and the growth and metabolism of those microorganisms are affected by various trace metal elements [7]. High levels of heavy metals are toxic and non-degradable, and hence are threats the environment safety [8]. A previous study 
demonstrated that trace metal elements (such as $\mathrm{Cu}, \mathrm{Ni}, \mathrm{Zn}, \mathrm{Cd}, \mathrm{Cr}$, and $\mathrm{Pb}$ ) had a certain inhibitory effect on anaerobic digestion at a high concentration [9]. Heavy metals had cytotoxic effects and were significant in biochemical reactions. They affected the activity of enzymes and microorganisms, and then impacted the biogas production efficiency of anaerobic fermentation [10]. A majority of studies showed that the toxic effect of trace heavy metals, $\mathrm{Cr}, \mathrm{Cd}$, and $\mathrm{Ni}$, on anaerobic fermentation was because of the combination of metal ions with thiols and other groups on proteins, which destroyed the structure and activity of enzymes $[9,11,12]$.

The demand for heavy metals may vary in different stages of anaerobic fermentation, and methanogenesis is the most metal-rich enzymatic pathway [13]. However, the demand trend for metals in all stages is basically the same: Fe is the most abundant metal, followed by $\mathrm{Ni}$ and $\mathrm{Co}$, with a small amount of Mo and $\mathrm{Zn}$ [14]. Tian et al. found that $\mathrm{Cd}$ and $\mathrm{Ni}$ were beneficial to biogas production in anaerobic fermentation at low concentrations [15]. The addition of Fe effectively resulted in the variation of cellulase during anaerobic fermentation, and then increased the cumulative biogas production (up to $18.1 \%$ ) and $\mathrm{CH}_{4}$ content (up to $8.3 \%$ ) [16]. Ni played an important role in the process of anaerobic digestion, mainly because the growth of all methanogens and the synthesis of cofactor $\mathrm{F}_{430}$ needed the participation of $\mathrm{Ni}$ [17]. It was found that the concentration of dissolved $\mathrm{Ni}$ over $1 \mathrm{mg} / \mathrm{L}$ would inhibit the methanogenesis process through the toxic metabolic of $\mathrm{Ni}$ tolerant degradative organisms in the process of anaerobic fermentation of sludge [18]. Another study showed that the concentration of Ni was between $12 \mathrm{mg} / \mathrm{m}^{3}$ and $5 \mathrm{~g} / \mathrm{m}^{3}$, which was the optimal culture concentration for methanogens [19]. The effect of $\mathrm{Ni}$ addition on anaerobic fermentation was mainly achieved by the action of Ni on cellulase activity and methanogenesis in different stages of fermentation [15].

The concurrence of different metals induced complex reactions and unpredictable results, which hindered the efficient utilization of biowaste. Lin et al. studied the degradation of volatile fatty acids (VFAs) by heavy metals and found that the addition of composite metals had a synergistic inhibitory effect on VFAs [20]. Ni showed synergistic effects with $\mathrm{Cu}, \mathrm{Mo}, \mathrm{Co}$, and mercury ( $\mathrm{Hg})$, and antagonistic effects with $\mathrm{Zn}$ and Cd [20]. In 1985, Ahring et al. proposed that Ni could reduce the toxicity of $\mathrm{Cd}$ and $\mathrm{Cu}$ [21]. As one of the worldwide environmental and health concerned heavy metals, $\mathrm{Cd}$ was able to impact the composition and diversity of bacterial communities in aerobic or anaerobic biological sludges used for wastewater treatment [22]. Once accumulated in the biomass, Cd would enter the fermenter and impact the anaerobic fermentation process [23]. The presence of $\mathrm{Cd}$ would induce different performances of anaerobic fermentation with $\mathrm{Fe}$ and $\mathrm{Ni}$ in the feedstocks. However, to the best of our knowledge, studies on the impacts of the $\mathrm{Cd}$ together with $\mathrm{Fe}$ and $\mathrm{Ni}$ on the anaerobic fermentation process were lacking, which hindered the efficient utilization of biowastes.

This study explored the effects of $\mathrm{Cd}$-containing heavy metals $(\mathrm{Cd}, \mathrm{Cd}+\mathrm{Fe}$, and $\mathrm{Cd}+\mathrm{Ni})$ on biogas yields and composition, $\mathrm{pH}$, oxidation reduction potential (ORP), $\mathrm{NH}_{4}{ }^{+}-\mathrm{N}, \mathrm{VFA}$ components, and microbial communities during thermophilic anaerobic fermentation of cow manure and corn stover. The influences of $\mathrm{Cd}, \mathrm{Cd}+\mathrm{Fe}$, and $\mathrm{Cd}+\mathrm{Ni}$ on biogas production, process stability, and biodegradation, as well as microorganisms, were then obtained and compared. In particular, the VFAs' generation and the relationship between VFA components and microorganisms were analyzed. This study is expected to lay the foundation for the application of heavy metal polluted biowaste in anaerobic fermentation.

\section{Materials and Methods}

\subsection{Experimental Materials}

Corn stover, the feedstock for anaerobic fermentation, was collected from the farmland in Tongzhou District, Beijing in November 2016. The harvested corn stover was air dried until moisture levels reached $<10 \%$. The dried stover was then ground into powder and passed through a $0.5 \mathrm{~mm}$ standard soil sieve. 
Fresh cow manure was used as an inoculum, which was collected from the Yanqing base, Beijing Dairy Cattle Centre. The total solid (TS) of the raw cow manure was $16.49 \% \pm 0.16 \%$ dry weight and the volatile solid (VS) was $84.00 \% \pm 0.48 \%$ of TS. No extra inoculum was used to start the experiment. The properties of corn stover and cow manure were the same as in the previous study [24]. The Cd contents in the corn stover and cow manure were lower than the limit of detection and were elided in this study.

\subsection{Anaerobic Fermentation Experiment}

The experiments were performed in the anaerobic fermenters (total volume of $30 \mathrm{~L}$, YGF 300/30, Shanghai Yangge Biological Engineering Equipment Co., Ltd., Shanghai, China) at $55.0 \pm 1.0^{\circ} \mathrm{C}$ for 28 days. The fermenters were autoclaved before each experiment. The working volume of the fermentation system was $20 \mathrm{~L}$. A stirrer with three layers of mixing blades was set in the middle of the reactor to ensure complete mixing of the substrates.

Equal amounts of corn stover and cow manure were mixed as the substrates for fermentation, that is, $0.8 \mathrm{~kg}$ dry weight for each. The TS of the substrate in the reactors was adjusted to $8 \%$ by adding distilled water. At the beginning of fermentation, $0.041 \mathrm{~g} \mathrm{CdCl}_{2} \cdot 2 \frac{1}{2} \mathrm{H}_{2} \mathrm{O}$ was added into the fermenters with a final $\mathrm{Cd}$ concentration of $1.0 \mathrm{mg} / \mathrm{L}$, which would not cause an inhibition according to the previous publication [23]. The group with only $\mathrm{Cd}$ addition was compared with experimental groups, adding extra $10.0 \mathrm{mg} / \mathrm{L} \mathrm{Fe}\left(0.712 \mathrm{~g} \mathrm{FeCl}_{2} \cdot 4 \mathrm{H}_{2} \mathrm{O}\right.$ addition $)$ and $2.0 \mathrm{mg} / \mathrm{L} \mathrm{Ni}\left(0.162 \mathrm{~g} \mathrm{NiCl}_{2} \cdot 6 \mathrm{H}_{2} \mathrm{O}\right.$ addition), respectively. The selection of metal concentrations was based on the previous researches on individual metal addition $[15,16,23]$, in which $1.0 \mathrm{mg} / \mathrm{L}$ initial Cd concentration, $10.0 \mathrm{mg} / \mathrm{L}$ initial Fe concentration, and $2.0 \mathrm{mg} / \mathrm{L}$ initial Ni concentration improved cumulative biogas yields. After adding metals, the fermenters were then infiltrated with high-purity nitrogen for $5 \mathrm{~min}$ to expel residual air.

\subsection{Measurements}

Biogas yields, $\mathrm{pH}$ values, and ORP were automatic measured at 09:00 every day [14]. TS was measured by weighing the samples after drying at $105^{\circ} \mathrm{C}$ for $24 \mathrm{~h}$. VS was measured after treating the samples in muffle for $550^{\circ} \mathrm{C}, 1 \mathrm{~h}$. Total nitrogen (TN) was measured using the Indophenol blue colorimetric method after being digested by concentrated sulfuric acid and 30\% hydrogen peroxide [25]. Total organic carbon (TOC) was measured by the potassium dichromate volumetric method [26]. $\mathrm{NH}_{4}{ }^{+}-\mathrm{N}$ and VFA were measured every three days via the sampling port at the bottom of the reactor. Briefly, about $200 \mathrm{~mL}$ of sample was collected after fully stirring the substrate. $\mathrm{NH}_{4}{ }^{+}-\mathrm{N}$ concentrations in the supernatant were obtained by Nessler's reagent [27] after centrifuging the sample at $5000 \mathrm{rpm}$ for $10 \mathrm{~min}$. Samples for VFA analysis were passed through a $0.45 \mu \mathrm{m}$ nitrocellulose membrane filter and frozen prior to analysis. VFA concentrations were measured using a gas chromatograph (GC-2014, Shimadzu Co., Kyoto, Japan) with a flame ionization detector (FID). VFA was expressed as mg/L of individual species ( $\mathrm{C} 2-\mathrm{C} 5$ fatty acids). $\mathrm{CH}_{4}$ contents in biogas were measured by a gas chromatograph (GC-2014C, Shimadzu Co., Kyoto, Japan) equipped with a GDX-401 column with $\mathrm{H}_{2}$ as the carrier gas. Detection was performed with a thermal conductivity detector (TCD).

The measurements of microbial communities were conducted by Novogene Co. Ltd (Beijing China) after certificating the samples at $8000 \mathrm{rpm}$ and $4{ }^{\circ} \mathrm{C}$ for $3 \mathrm{~min}$. Briefly, the genomic DNA of the samples on the 7th, 13th, and 19th day were extracted by the cetyltrimethylammonium ammonium bromide (CTAB) methods [28]. After the extraction, the samples were diluted to a concentration of $1 \mathrm{ng} / \mathrm{L}$ with sterile water. Then, the diluted genomic DNA was used as the template for PCR amplification. PCR amplification of the V3-V4 hypervariable region of bacterial 16S rDNA was performed using universal primers 338 F (50-ACTCCTACGGGAGGCAGCAG-30) and 806 R (50-GGACTACHVGGGTWTCTAAT-30) [29]. Archaea primers used to amplify the V3-V4 hypervariable region of archaeal 16S rDNA were 344 F (50-ACGGGGYGCAGCAGGCGCGA-30) and 806 R (50-GGACTACVSGGGTATCTAAT-30). All primers included Illumina barcode sequences for multiplexing each sample. The library construction was conducted with TruSeq ${ }^{\circledR}$ DNA PCR-Free 
Sample Preparation Kit. After the Qubit and Q-PCR quantification, the constructed library was qualified and HiSeq2500 PE250 was used for sequencing.

\subsection{Data Analysis}

After removing the barcode and primers' sequences, the reads were matched with FLASH (V1.2.7) for raw Tags and then sieved for clean Tags. Clean Tags were cut out and the length filtered by referencing the Qiime quality control process (V1.9.1). The obtained Tags were treated by removing the chimeric sequence through comparison with the detection chimeric sequence (Gold database), yielding the final effective Tags as the targets. The cluster analysis of effective Tags was conducted using Uparse software (V7.0.1001). The operational taxonomic units (OTUs) were clustered with identity $>97 \%$. Species annotation of the OTUs' representative sequence was carried out using the Mothur method and Small subunit ribosomal RNA (SSUrRNA) database (define threshold of 0.8-1.0). The microbial communities were then obtained after annotation.

The data in the study were the average of three parallel repeats. Error bars represent the standard errors of the mean: $\mathrm{SEM}=\mathrm{SD} / \sqrt{\mathrm{n}}$, where $\mathrm{SD}$ is the standard deviation. One-way analysis of variance (one-way ANOVA) and Pearson correlation analysis were performed in Statistical Package for the Social Science (SPSS, 17.0, Chicago, IL, USA) software at 0.05 and 0.01 levels of significance, represented by $^{*}(p<0.05)$ and ${ }^{* *}(p<0.01)$, respectively.

\section{Results and Discussion}

\subsection{Biogas Properties}

\subsubsection{Cumulative and Daily Biogas Yields}

Figure 1 a shows the impact of $\mathrm{Fe}$ and $\mathrm{Ni}$ combined with $\mathrm{Cd}$ addition on cumulative biogas yields. The cumulative biogas yields of the $\mathrm{Cd}+\mathrm{Ni}$ and $\mathrm{Cd}+\mathrm{Fe}$ groups were enhanced by $119.76 \%$ and $80.89 \%$, respectively, compared with the control group (only Cd added). The biogas yield of the $\mathrm{Cd}+$ $\mathrm{Ni}$ group far exceeded that of the control group in the first seven days. This was mainly because $\mathrm{Ni}$ was the active central component of the main enzyme involved in anaerobic fermentation and played a key role in the formation of $\mathrm{CH}_{4}$ by methyl coenzyme $\mathrm{M}$ reductase (MCR) [30,31]. Compared with the $\mathrm{Cd}$ group, the addition of $\mathrm{Cd}+\mathrm{Ni}$ increased the activity of the enzyme. The result indicated that the addition of $\mathrm{Cd}+\mathrm{Ni}$ was beneficial to start the anaerobic fermentation and usher in the peak of biogas yield in advance. The cumulative biogas yield of the $\mathrm{Cd}+\mathrm{Fe}$ group surpassed that of the control group from the eighth day, which was partly because of the fact that Fe was the most abundant metal element in the tissue of methanogenic bacteria, and was necessary for the synthesis of various enzymes in the anaerobic fermentation (such as CO dehydrogenase, acetyl coenzyme A synthase, and hydrogenase), and could activate the activity of related enzymes [32]. Besides, the addition of Fe was able to reduce the concentration of dissolved sulfides during anaerobic fermentation, thus lowering the toxicity of sulfides to microorganisms [33]. After the 20th day, the cumulative biogas yield curve of the Cd and $\mathrm{Cd}+\mathrm{Fe}$ groups reached a plateau, while that of the $\mathrm{Cd}+\mathrm{Ni}$ group was still ascending.

The effects of $\mathrm{Cd}, \mathrm{Cd}+\mathrm{Fe}$, and $\mathrm{Cd}+\mathrm{Ni}$ addition on the daily biogas yields are shown in Figure $1 \mathrm{~b}$. The highest daily biogas yields were 15.56, 34.64, and $44.07 \mathrm{~mL} / \mathrm{g}$ TS for the $\mathrm{Cd}, \mathrm{Cd}+\mathrm{Fe}$, and $\mathrm{Cd}+\mathrm{Ni}$ groups, respectively. The control group had two peaks of biogas yield throughout the fermentation. According to a previous study, the first biogas yield peak was caused by the degradation of cow manure, while the second biogas yield peak was the result of the degradation of corn stover [23]. Meanwhile, two peaks of the $\mathrm{Cd}+\mathrm{Fe}$ group were only two days apart, and only one peak of the $\mathrm{Cd}+\mathrm{Ni}$ group appeared. This indicated that the addition of $\mathrm{Cd}+\mathrm{Fe}$ and $\mathrm{Cd}+\mathrm{Ni}$ was beneficial to improve the hydrolysis efficiency of the non-degradable materials in the substrate and shorten the gap between the peaks of biogas yield. Thus, the additions of Fe and Ni into the Cd-containing anaerobic fermentation system were able to improve and bring forward the daily biogas peak. The above results 
showed that the addition of $\mathrm{Cd}+\mathrm{Fe}$ and $\mathrm{Cd}+\mathrm{Ni}$ improved the biogas yields of anaerobic fermentation compared with the control group, and the promotion effect of the $\mathrm{Cd}+\mathrm{Ni}$ group on biogas yield was greater than that of the $\mathrm{Cd}+\mathrm{Fe}$ group.
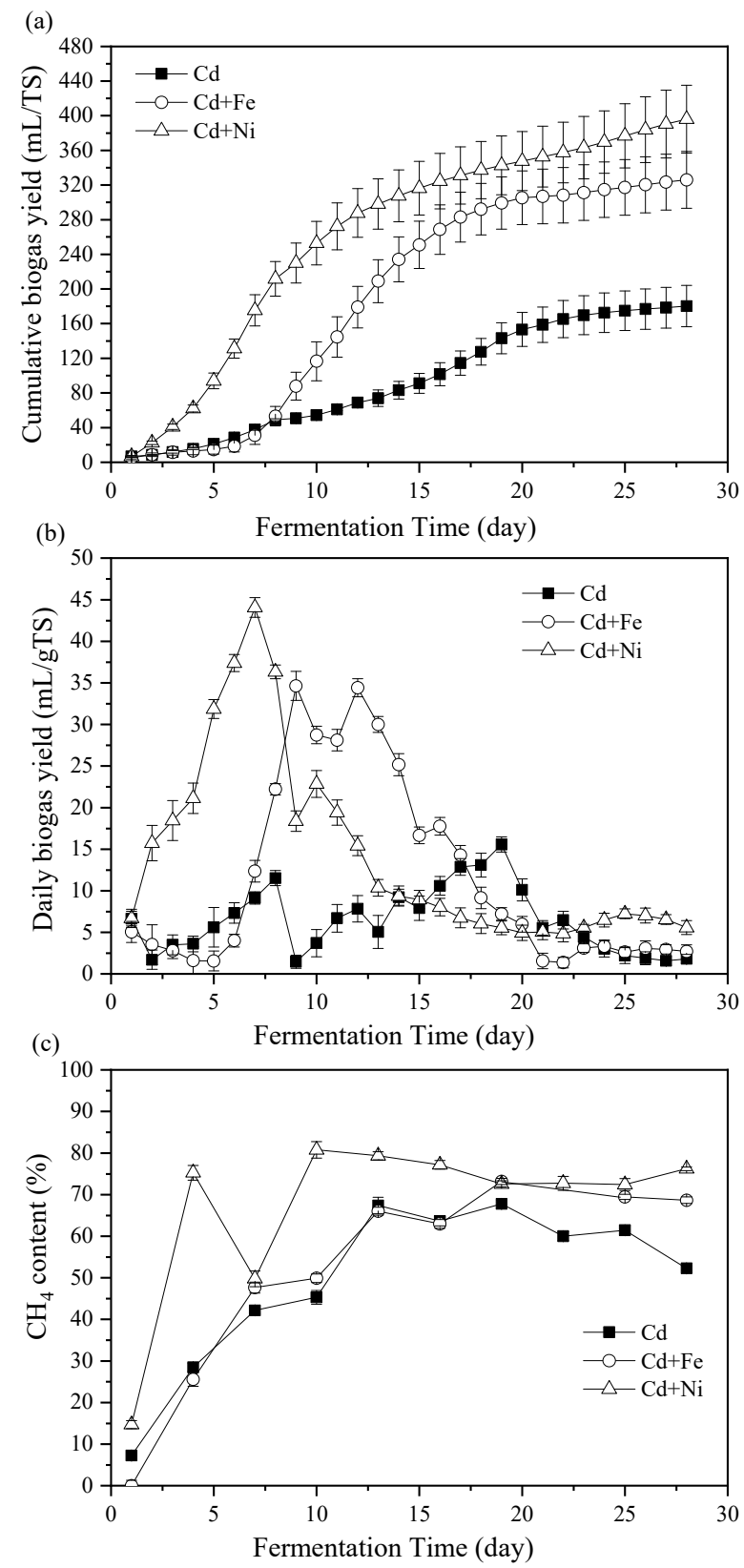

Figure 1. Cumulative biogas yields (a), daily biogas yield (b), and $\mathrm{CH}_{4}$ contents (c) in response to $\mathrm{Cd}$, $\mathrm{Cd}+\mathrm{Fe}$, and $\mathrm{Cd}+\mathrm{Ni}$ addition during the fermentation.

\subsection{2. $\mathrm{CH}_{4}$ Content}

The percentage of $\mathrm{CH}_{4}$ in biogas was determined to compare the energy conversion efficiency and the impact of heavy metals addition. Figure $1 \mathrm{c}$ reports the $\mathrm{CH}_{4}$ content of the biogas in the $\mathrm{Cd}$, $\mathrm{Cd}+\mathrm{Fe}$, and $\mathrm{Cd}+\mathrm{Ni}$ groups. During the first four days of fermentation, the $\mathrm{CH}_{4}$ contents and the corresponding cumulative biogas yields in the $\mathrm{Cd}$ and $\mathrm{Cd}+\mathrm{Fe}$ groups were not obviously different. The $\mathrm{CH}_{4}$ content of the $\mathrm{Cd}+\mathrm{Ni}$ group was higher than that of the $\mathrm{Cd}+\mathrm{Fe}$ and control groups, indicating the accelerating impact of $\mathrm{Cd}+\mathrm{Ni}$ on the start-up of the fermentation. However, on the seventh day, the $\mathrm{CH}_{4}$ content in the $\mathrm{Cd}+\mathrm{Ni}$ group suddenly decreased; on the contrary, the daily biogas yield 
reached the maximum. This could be because of the relatively low activity of methanogens at this time, which was caused by the sharp variation of $\mathrm{pH}$ values after the fifth day (Figure 2), and further affected the methanogenesis process of the $\mathrm{Cd}+\mathrm{Ni}$ group. Along with the stability of the fermentation system and the adaption of microorganisms, the hydrolytic products were used by methanogens, resulting in an increase in $\mathrm{CH}_{4}$ content on the 10th day. The highest $\mathrm{CH}_{4}$ contents were $67.77 \%, 73.17 \%$, and $80.76 \%$ for the $\mathrm{Cd}, \mathrm{Cd}+\mathrm{Fe}$, and $\mathrm{Cd}+\mathrm{Ni}$ groups, respectively. The $\mathrm{CH}_{4}$ content in the $\mathrm{Cd}+\mathrm{Ni}$ group was greater than that of the $\mathrm{Cd}$ and $\mathrm{Cd}+\mathrm{Fe}$ groups. The $\mathrm{CH}_{4}$ content in the $\mathrm{Cd}+\mathrm{Ni}$ group in this study was higher than in the previous report $(70.41 \%)$ when only $2.0 \mathrm{mg} / \mathrm{L} \mathrm{Ni}$ was added to reed and cow dung [15]. Similarly, the maximum $\mathrm{CH}_{4}$ content in $\mathrm{Cd}+\mathrm{Fe}$ in this study was higher than that of $\mathrm{CH}_{4}$ content $(45.33 \%)$ adding $10.0 \mathrm{mg} / \mathrm{L} \mathrm{Fe}$ alone in a previous study [16]. Therefore, the additions of $\mathrm{Cd}+\mathrm{Ni}$ and $\mathrm{Cd}+\mathrm{Fe}$ were beneficial to increase the content of $\mathrm{CH}_{4}$ in the fermentation process and improve the quality of biogas.

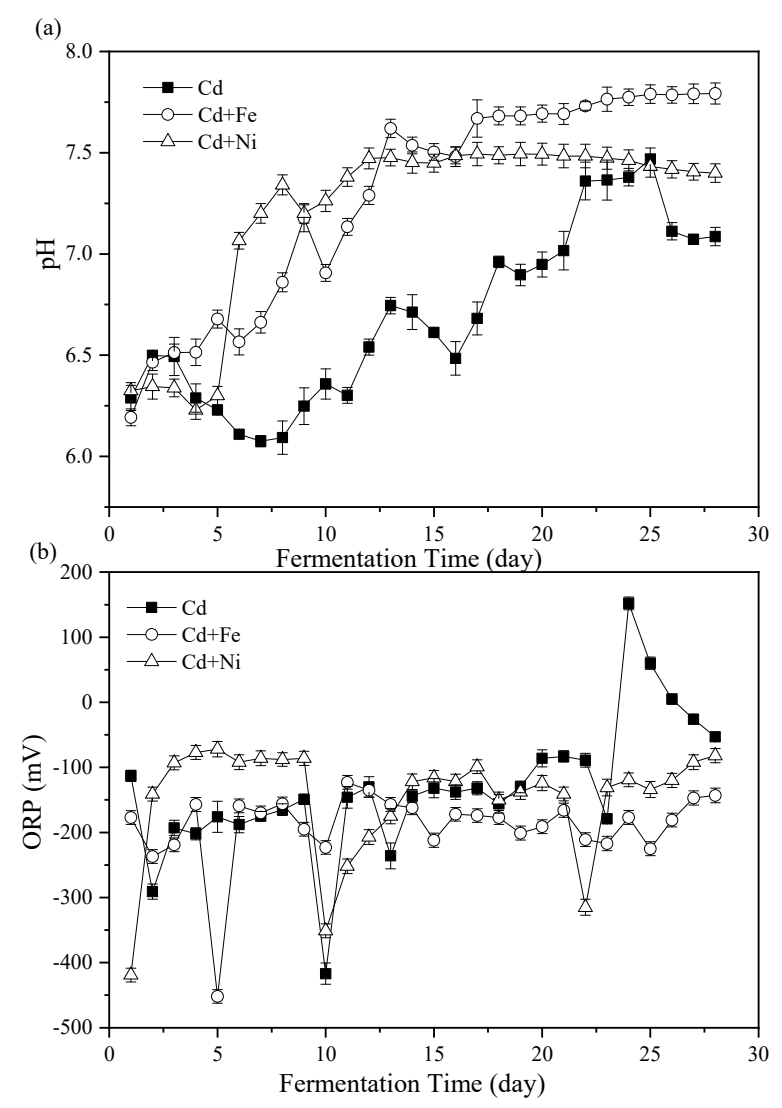

Figure 2. Impact of $\mathrm{Cd}, \mathrm{Cd}+\mathrm{Fe}$, and $\mathrm{Cd}+\mathrm{Ni}$ addition on $\mathrm{pH}$ values (a) and oxidation reduction potential (ORP) (b) during the fermentation.

\subsection{Process Stability}

\subsection{1. $\mathrm{pH}$ Values}

The importance of $\mathrm{pH}$ values on representing the status of fermenters and impacting the activity of microbial communities has been widely considered [34,35]. The variations of $\mathrm{pH}$ values during the fermentation process are shown in Figure 2a. Overall, the $\mathrm{pH}$ of the $\mathrm{Cd}+\mathrm{Fe}$ and $\mathrm{Cd}+\mathrm{Ni}$ groups increased in the first few days of fermentation, then decreased, and finally rose to a stable state, while the $\mathrm{pH}$ of the control group was always unstable. In general, during the start-up stage of fermentation, organic substances in the substrate were rapidly hydrolyzed to acid, which led to the accumulation of acidic hydrolysates, resulting in lower $\mathrm{pH}$ value and lower biogas production. In the latter stage, the $\mathrm{pH}$ increased and stabilized through the utilization of VFA by methanogens [14]. However, the results 
in this study were different from this situation. At the beginning of fermentation (first two days), the $\mathrm{pH}$ of all groups increased. On one hand, the acid-producing microorganism in the fermentation system might not be adapted to the environment, resulting in less acid components in anaerobic fermentation. On the other hand, the increase in $\mathrm{NH}_{4}{ }^{+}-\mathrm{N}$ concentration (Figure 3 ) could buffer the acid components produced. In addition, there may be other acid-base substances in anaerobic fermentation that affected the increase of $\mathrm{pH}$ values. With the progress of anaerobic fermentation, the activity of acid-producing microorganisms was enhanced, and the acid-producing process was the rate-limiting step [36]. The $\mathrm{pH}$ of all groups in the anaerobic fermentation decreased. In the middle stage of fermentation, the $\mathrm{CH}_{4}$-producing stage dominated and the acid components generated in the acid producing stage were consumed, so the $\mathrm{pH}$ increased and eventually tended to be stable [36]. With the development of fermentation, the $\mathrm{pH}$ of the control group decreased for a long time (third to eighth day) as a result of the accumulation of acid components in the acid production stage. The $\mathrm{pH}$ of the $\mathrm{Cd}+\mathrm{Ni}$ group and the $\mathrm{Cd}+\mathrm{Fe}$ group decreased for a short time and increased rapidly, which might be because of the synergistic effects of the heavy metals in the process of $\mathrm{CH}_{4}$ production, and the more efficient utilization of acid components by methanogens [31]. Therefore, the $\mathrm{pH}$ of the $\mathrm{Cd}+\mathrm{Ni}$ and $\mathrm{Cd}+\mathrm{Fe}$ groups did not decrease remarkably, and the average $\mathrm{pH}$ of the whole fermentation process was $8.82 \%$ and $7.77 \%$ higher, respectively, than the control group.

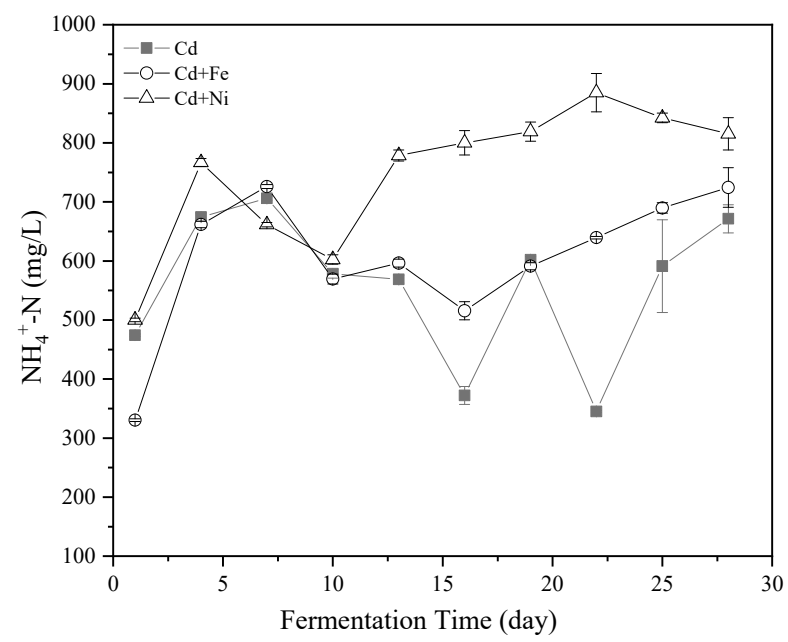

Figure 3. Impact of $\mathrm{Cd}, \mathrm{Cd}+\mathrm{Fe}$, and $\mathrm{Cd}+\mathrm{Ni}$ addition on $\mathrm{NH}_{4}{ }^{+}-\mathrm{N}$ concentrations during the fermentation.

During the whole fermentation process, the average $\mathrm{pH}$ values of the $\mathrm{Cd}, \mathrm{Cd}+\mathrm{Fe}$, and $\mathrm{Cd}+\mathrm{Ni}$ groups were $6.69 \pm 0.12,7.28 \pm 0.15$, and $7.21 \pm 0.21$, respectively, which were all located in the $\mathrm{pH}$ range suitable for anaerobic microorganisms [37]. From the 5th day to 13th day, the increase of $\mathrm{pH}$ toward the neutral condition in the $\mathrm{Cd}+\mathrm{Ni}$ and $\mathrm{Cd}+\mathrm{Fe}$ group corresponded with the achievement of the peak biogas stage. After the 13th day, the $\mathrm{pH}$ of the $\mathrm{Cd}+\mathrm{Fe}$ and $\mathrm{Cd}+\mathrm{Ni}$ groups began to stabilize, while the $\mathrm{pH}$ of the control group changed remarkably. This result indicated that the additions of $\mathrm{Cd}+$ $\mathrm{Fe}$ and $\mathrm{Cd}+\mathrm{Ni}$ were beneficial to improve the stability of the fermentation process and enhance the acid-base buffering capacity of the fermentation system.

\subsubsection{Oxidation Reduction Potential (ORP)}

The ORP value represented the oxidation reduction reactions in the fermenters and was a useful parameter to monitor the fermentation process [38]. The effects of $\mathrm{Cd}, \mathrm{Cd}+\mathrm{Fe}$, and $\mathrm{Cd}+\mathrm{Ni}$ on ORP values during fermentation are shown in Figure $2 \mathrm{~b}$. On the first day, the ORP values of the groups were in the order of $\mathrm{Cd}+\mathrm{Ni}<\mathrm{Cd}+\mathrm{Fe}<\mathrm{Cd}$. From the second to the ninth day of fermentation, the ORP values of the $\mathrm{Cd}$ and $\mathrm{Cd}+\mathrm{Fe}$ groups decreased and fluctuated, while the ORP value of the $\mathrm{Cd}+$ $\mathrm{Ni}$ group was higher and stable. The results showed that the redox state of anaerobic fermentation 
in the $\mathrm{Cd}+\mathrm{Ni}$ group was placid. During this period, the daily biogas yield and $\mathrm{CH}_{4}$ content of the $\mathrm{Cd}+\mathrm{Ni}$ group were higher than those of the other groups. The ORP value of the $\mathrm{Cd}+\mathrm{Fe}$ group remained relatively stable, while the ORP value of the control group increased starting from the 10th day of fermentation.

\subsection{Substrate Biodegradation}

\subsection{1. $\mathrm{NH}_{4}{ }^{+}-\mathrm{N}$ Concentration}

$\mathrm{NH}_{4}{ }^{+}-\mathrm{N}$ was one of the sources of nutrient elements required by anaerobic microorganisms. An appropriate amount of $\mathrm{NH}_{4}{ }^{+}-\mathrm{N}$ could promote the activity of methanogens [39]. The methanogens, as members of the archaea, were among the microbial populations most sensitive to $\mathrm{NH}_{4}{ }^{+}-\mathrm{N}$ in anaerobic fermentation [40]. In addition, $\mathrm{NH}_{4}{ }^{+}-\mathrm{N}$ affected the activity of $\mathrm{CH}_{4}$ synthase. The effects of $\mathrm{Cd}, \mathrm{Cd}+$ $\mathrm{Fe}$, and $\mathrm{Cd}+\mathrm{Ni}$ on the $\mathrm{NH}_{4}{ }^{+}-\mathrm{N}$ concentrations in the fermentation are shown in Figure 3. Overall, the $\mathrm{NH}_{4}{ }^{+}-\mathrm{N}$ concentrations in all of the groups followed the same trend of an increase first and then a decrease. However, there was still a big difference between the compound metal added groups and the control group. The $\mathrm{NH}_{4}{ }^{+}-\mathrm{N}$ concentration on the fourth day was highest in the $\mathrm{Cd}+\mathrm{Ni}$ group because of the addition of $\mathrm{Ni}$ contributing to the release of the nitrogen source. After the 10th day, the concentrations of $\mathrm{NH}_{4}{ }^{+}-\mathrm{N}$ in the control group varied greatly, while the concentrations of $\mathrm{NH}_{4}{ }^{+}-\mathrm{N}$ in the compound metals groups were relatively stable. During this period, the order of $\mathrm{NH}_{4}{ }^{+}-\mathrm{N}$ concentration was $\mathrm{Cd}+\mathrm{Ni}>\mathrm{Cd}+\mathrm{Fe}>\mathrm{Cd}$, which was same as the order of cumulative biogas yield.

$\mathrm{NH}_{4}{ }^{+}-\mathrm{N}$ was reported to promote the production of $\mathrm{CH}_{4}$ when the concentration was $<6000$ $\mathrm{mg} / \mathrm{L}$, while $\mathrm{NH}_{4}{ }^{+}-\mathrm{N}$ was able to increase the alkalinity of the fermentation system and the buffering of VFA [41]. High $\mathrm{NH}_{4}{ }^{+}-\mathrm{N}$ concentrations brought high free ammonia nitrogen, which has been a main cause of inhibition owing to its high permeability to the bacterial cell membrane. Ammonia might affect methanogens in two ways: (i) ammonium ion inhibited the $\mathrm{CH}_{4}$ producing enzymes directly, and/or (ii) hydrophobic ammonia molecule diffused passively into bacterial cells, causing proton imbalance or potassium deficiency [42]. In the present study, the peak of $\mathrm{NH}_{4}{ }^{+}-\mathrm{N}$ concentration of all groups was far below $6000 \mathrm{mg} / \mathrm{L}$. Therefore, the addition of $\mathrm{Cd}$ together with Fe and Ni enhanced the stability of the $\mathrm{NH}_{4}{ }^{+}-\mathrm{N}$ concentration, which in turn helped to buffer the $\mathrm{pH}$ of the fermentation solution, making the fermentation system more suitable for producing $\mathrm{CH}_{4}$.

\subsubsection{Responses of VFA}

The concentrations of total VFA and the compositions, that is, acetic acid, propionic acid, butyric acid, valeric acid, and isovaleric acid, are presented in Figure 4. Overall, the VFA concentrations of all the groups in the initial stage were higher than in the middle and late stage of the fermentation. During the first 10 days of fermentation, total VFA concentrations of the $\mathrm{Cd}+$ Fe group were higher than those of the $\mathrm{Cd}$ and $\mathrm{Cd}+\mathrm{Ni}$ groups, with the peak concentration of total VFA on the seventh day. During this period, despite the high total VFA concentrations, the $\mathrm{pH}$ values did not declined because alkaline components were generated as well, such as $\mathrm{NH}_{4}{ }^{+}-\mathrm{N}$ (Figure 3). The VFA concentration in the $\mathrm{Cd}$ $+\mathrm{Ni}$ group increased from the first to the fourth day, as did the daily biogas yields. On the seventh day, the increases of VFA in the $\mathrm{Cd}$ and $\mathrm{Cd}+\mathrm{Fe}$ groups were observed together with the increment of daily biogas yields. The synchronous increases of total VFA and daily biogas yields suggested that the VFA was efficiently generated and consumed for biogas production. On the 13th day, the VFA concentration in the $\mathrm{Cd}+\mathrm{Fe}$ group decreased sharply, while the daily biogas yield increased to a maximum. This result indicated that the rate of VFA consumed by biogas production was higher than the rate of VFA produced. 


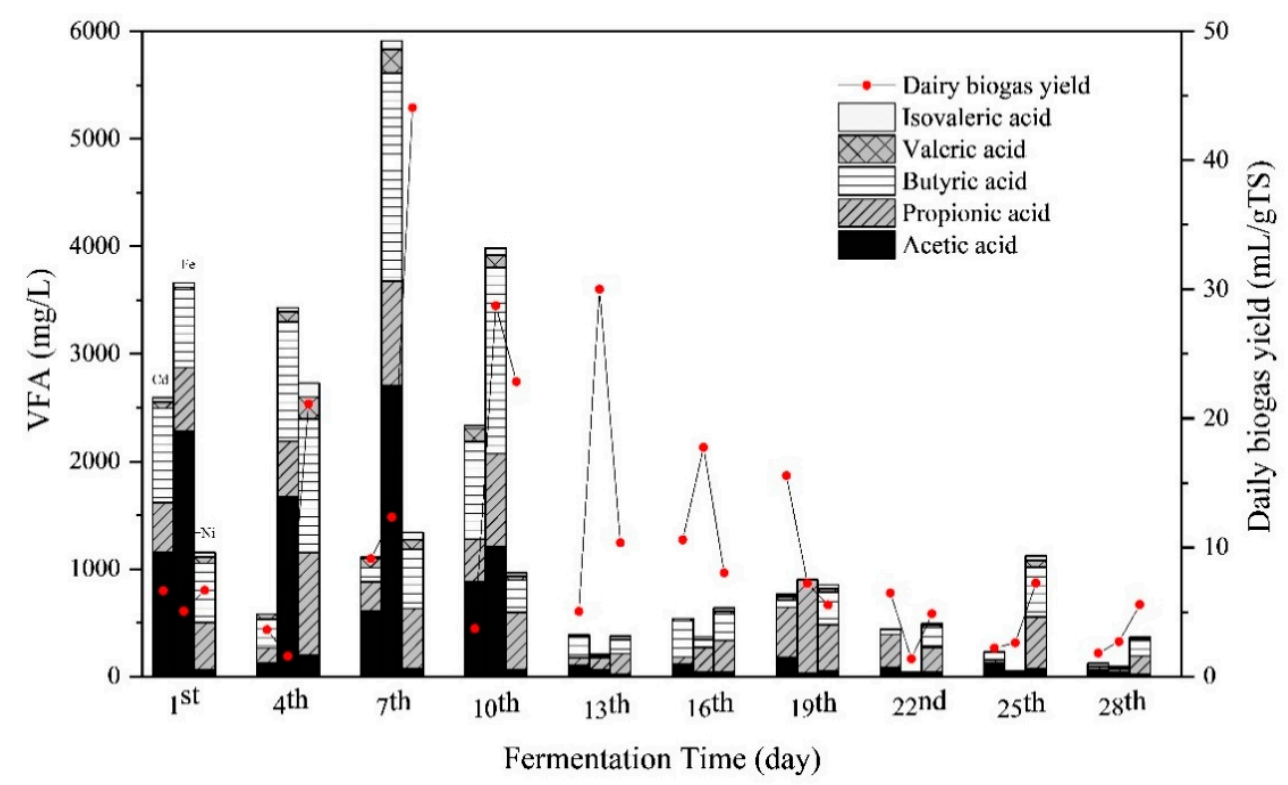

Figure 4. Impact of $\mathrm{Cd}, \mathrm{Cd}+\mathrm{Fe}$, and $\mathrm{Cd}+\mathrm{Ni}$ addition on volatile fatty acids (VFAs) and daily biogas yield during the fermentation.

The main compositions of VFA varied with metal additions. During the first seven days, acetic acid was the main composition of VFA, followed by butyric acid $>$ propionic acid $>$ valeric acid in the $\mathrm{Cd}$ and $\mathrm{Cd}+\mathrm{Fe}$ groups. However, the order of the VFA compositions was butyric acid $>$ propionic acid $>$ acetic acid $>$ valeric acid in the $\mathrm{Cd}+\mathrm{Ni}$ group. Among all VFAs, acetic acid and butyric acid were the most favorable for $\mathrm{CH}_{4}$ formation, while contribution of acetic acid was more than $70 \%$ [43]. Thus, acetic acid was efficiently used for the methanogenesis in the $\mathrm{Cd}+\mathrm{Ni}$ group, which contributed to the higher biogas and $\mathrm{CH}_{4}$ yields. During the anaerobic fermentation process, the average VFA concentration in the $\mathrm{Cd}+\mathrm{Ni}$ group was lower than that in the $\mathrm{Cd}+\mathrm{Fe}$ group, indicating that the VFA consumption rate in the $\mathrm{Cd}+\mathrm{Ni}$ group was higher than that in the $\mathrm{Cd}+\mathrm{Fe}$ group. Meanwhile, $\mathrm{Ni}$ was previously proved to be the most effective element compared with $\mathrm{Fe}, \mathrm{Co}$, and Mo, exhibiting the maximum increment of biogas yield [30]. Therefore, the biogas yield of the $\mathrm{Cd}+\mathrm{Ni}$ group was higher than that of the $\mathrm{Cd}+\mathrm{Fe}$ group. After the 10th day, the concentrations of VFA compositions in all groups decreased.

Figure 5 shows the Pearson correlation between $\mathrm{pH}$ values and VFA concentrations. There were significantly negative correlations between $\mathrm{pH}$ values and VFA concentrations in the $\mathrm{Cd}+\mathrm{Fe}$ $(-0.781, p<0.01)$ and $\mathrm{Cd}+\mathrm{Ni}(-0.875, p<0.01)$ groups. Previous studies showed that the increase and accumulation of VFA concentrations resulted in a corresponding decrease in the $\mathrm{pH}$ value of suspension, and both VFA concentrations and the $\mathrm{pH}$ values of suspension affected the activity of hydrolytic microorganisms in an anaerobic environment [44]. At the beginning of fermentation, the organic matter in the substrate was rapidly hydrolyzed to acid, such as VFA, which cannot be effectively used for methanogenesis owing to the slow adaptation and metabolism of methanogens. Therefore, the accumulation of acidic hydrolyzed products led to a decrease in $\mathrm{pH}$ and a low biogas yield [45]. In the control group, $\mathrm{pH}$ values were not correlated to VFA concentrations. This was probably because of the influence of other acid-base substances on $\mathrm{pH}$ in the control group, which needed further study and analysis. 


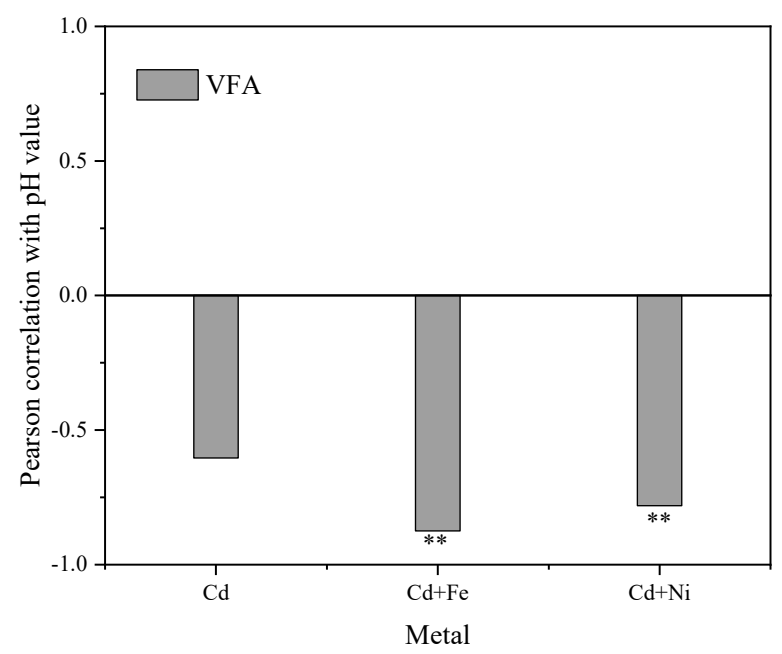

Figure 5. Relationships between $\mathrm{pH}$ values and VFA concentrations during the fermentation. $* *, p<0.01$.

\subsection{Microbial Properties}

\subsubsection{Structure of Bacterial Communities}

The variations of bacterial communities annotated on the level of genus are shown in Figure 6. It was found that the compound metals exerted different influences on bacterial communities as the fermentation progressed. The changes in bacterial community mainly manifested in the relative abundance of the same bacterial genus at different fermentation stages. On the seventh day, the dominant bacteria of the Cd addition group were recognized as Ruminiclostridium, Mobilitalea, Tepidimicrobium, and Ruminiclostridium_1. As previously reported by Fosses et al., Ruminiclostridium cellulolyticum was able to produce extracellular multi enzymatic complexes called cellulosomes, which efficiently degraded the crystalline cellulose and the cell wall [46]. Mobilitalea was reported as a novel strictly anaerobic, halotolerant, organotrophic bacterium, strain P3M-3T. Strain P3M-3T grew optimally at $37^{\circ} \mathrm{C}, \mathrm{pH} 7.0-7.5$, and in an $\mathrm{NaCl}$ concentration of $15 \mathrm{~g} / \mathrm{L}$ [47]. Under optimum growth conditions, the doubling time was $1 \mathrm{~h}$. Mobilitalea was able to ferment a variety of mono-, di-, and polysaccharides, including microcrystalline cellulose [47]. Tepidimicrobium was anaerobic, moderately thermophilic and neutrophilic, with the temperature range for growth of $25-67^{\circ} \mathrm{C}$, and $\mathrm{pH}$ range for growth of 5.5-9.5 [48]. Tepidimicrobium spp. grew organotrophically on a number of proteinaceous substrates, amino acids, and carbohydrates and produced acid, ethanol, $\mathrm{H}_{2}$, and $\mathrm{CO}_{2}$ [48]. Therefore, the detected bacterial communities in the $\mathrm{Cd}$ addition group supported the degradation of carbohydrates and proteins as well as the generation of $\mathrm{CH}_{4}$.

In the $\mathrm{Cd}+\mathrm{Fe}$ group, the dominant bacteria were Ruminiclostridium, Tepidimicrobium, Caproiciproducens, and Ruminiclostridium_1 on the seventh day. Caproiciproducens was a strictly anaerobic, Gram-stain-positive, non-spore-forming, rod-shaped bacterial strain [49]. They grew at $35-45^{\circ} \mathrm{C}$ and $\mathrm{pH}$ of 6.0-8.0, and produced $\mathrm{H}_{2}, \mathrm{CO}_{2}$, ethanol, acetic acid, butyric acid, and caproic acid as metabolic end products of anaerobic fermentation [49]. Ruminiclostridium and Ruminiclostridium_1 were increased on the 13th and 19th day alongside the reduction of Tepidimicrobium and Caproiciproducen. The result suggested that, as the fermentation progressed, the substrate was continuously consumed, resulting in a decreased relative abundance of Tepidimicrobium and Caproiciproducen.

In the $\mathrm{Cd}+\mathrm{Ni}$ group, the relative abundance of Ruminiclostridium_1 was the highest, followed by Tepidimicrobium, Defluviitoga, and Mobilitalea, on the seventh day. A new isolate L3 of Defluviitoga tunisiensis presumably was able to degrade cellulose, as genes encoding cellulases were identified in its genome [50]. Acetate, $\mathrm{H}_{2}$, and $\mathrm{CO}_{2}$ were supposed to be end products of the fermentation process. The 
relative abundance of Defluviitoga was highest on the 19th day. Therefore, $\mathrm{H}_{2}$ and $\mathrm{CO}_{2}$ were efficiently generated and used for $\mathrm{CH}_{4}$ production at this time.

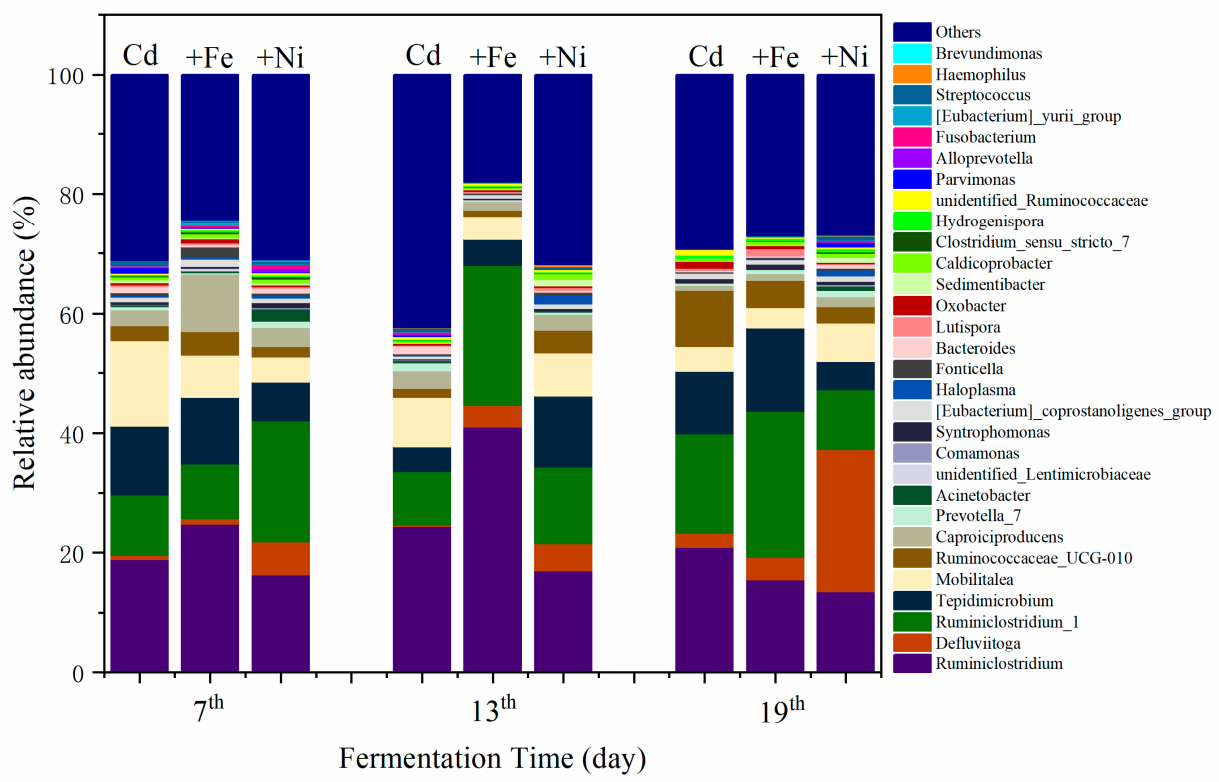

Figure 6. Impact of $\mathrm{Cd}, \mathrm{Cd}+\mathrm{Fe}$, and $\mathrm{Cd}+\mathrm{Ni}$ addition on the structure of bacterial communities during the fermentation.

\subsubsection{Methanogens and Their Relationships with Fermentation Parameters}

According to the results of clustering and species annotation of OTUs, the absolute abundance in the fermentation system at the archaeal genus level on the 7th, 13th, and 19th was analyzed to focus on the variation of methanogens. Figure 7 shows the effect of $\mathrm{Cd}, \mathrm{Cd}+\mathrm{Fe}$, and $\mathrm{Cd}+\mathrm{Ni}$ addition on the absolute abundance of seven methanogens, namely Methanothermobacter, Methanobrevibacter, Methanobacterium, Methanosphaera, Methanocorpusculum, and Candidatus_Methanoplasma.

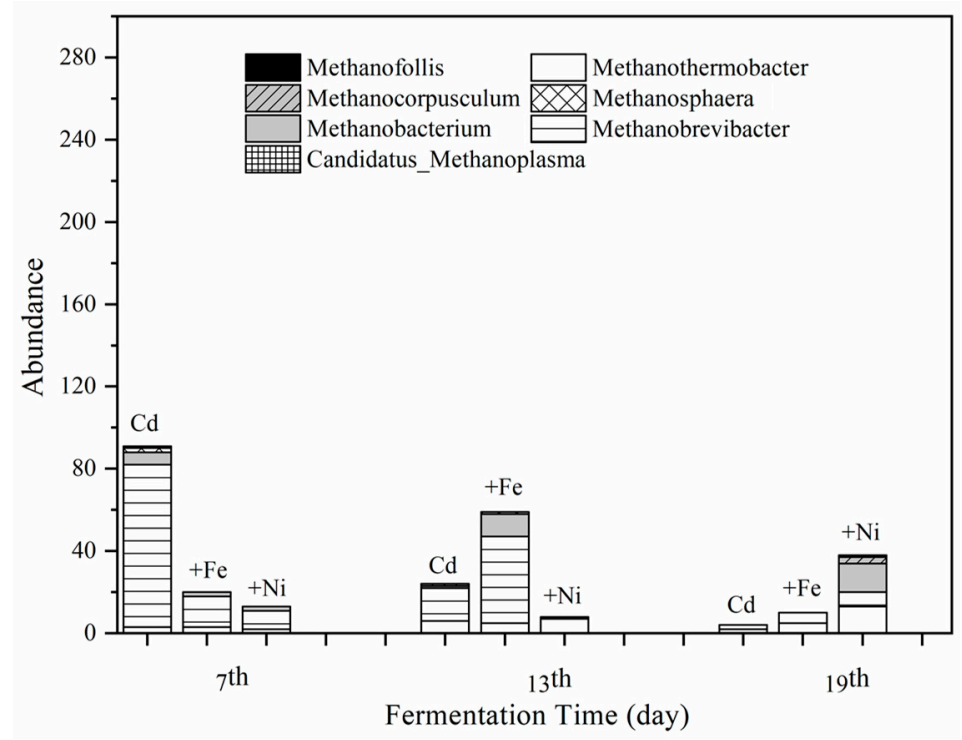

Figure 7. Impact of $\mathrm{Cd}, \mathrm{Cd}+\mathrm{Fe}$, and $\mathrm{Cd}+\mathrm{Ni}$ addition on the absolute abundance of methanogens during the fermentation.

It can be seen from Figure 7 that the total abundance of methanogens in the $\mathrm{Cd}$ added group on the seventh day was much higher than that of the other groups with Methanobrevibacter as the dominant 
genus. All of the Methanobrevibacter species are hydrogenotrophs [51] and use $\mathrm{H}_{2}$ and formate as substrate for their $\mathrm{CH}_{4}$ production [52]. However, the Methanobrevibacter in the $\mathrm{Cd}+\mathrm{Ni}$ group was not of a large amount, which was probably caused by the low concentrations and bioavailability of $\mathrm{Ni}$. The total abundance of methanogens in the $\mathrm{Cd}+\mathrm{Fe}$ group on the 13th day was higher than that of the other groups with Methansobrevibacter as the dominant genus, followed by Methanobacterium. The total abundance of methanogens in the $\mathrm{Cd}+\mathrm{Ni}$ group was higher than that of the other groups on the 19th day. The main methanogens in this group on the 19th day were identified as Methanothermobacter and Methanobacterium.

The relationships between the methanogens and fermentation parameters according to the Pearson correlation analysis are shown in Figure 8. The vertical direction is the information of different environmental factors, and the horizontal direction is the representation of the methanogens' information. In the Cd added group, Methanobrevibacter $(p<0.01)$ and Methanobacterium $(p<0.05)$ were negatively correlated to $\mathrm{pH}$. In the $\mathrm{Cd}+$ Fe group, Methanothermobacter was positively correlated to $\mathrm{pH}(p<0.05)$, but negatively correlated to $\mathrm{NH}_{4}{ }^{+}-\mathrm{N}(p<0.05)$ and acetic acid $(p<0.01)$. Besides, Methanobrevibacter $(p<0.05)$ and Methanobacterium $(p<0.05)$ were positively correlated to daily biogas yields in the presence of Fe. There was no significant relationship between the methanogens and fermentation parameters in the $\mathrm{Cd}+\mathrm{Ni}$ group.

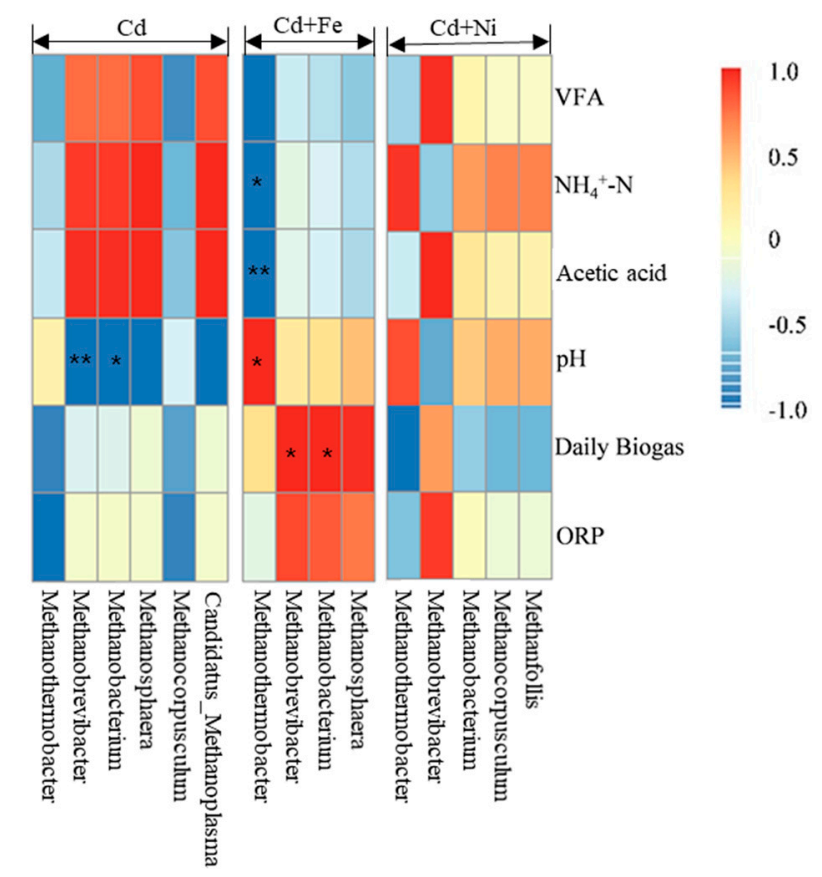

Figure 8. Pearson correlation analysis between environmental factors and methanogen under $\mathrm{Cd}, \mathrm{Cd}+$ $\mathrm{Fe}$, and $\mathrm{Cd}+\mathrm{Ni}$ addition during the fermentation.

As can be seen from the above results, there were obvious bacterial community structure changes in different fermentation stages of all compound metals groups. Ruminiclostridium, Mobilitalea, Tepidimicrobium Ruminiclostridium_1, Caproiciproducens, and Defluviitoga were the dominant genus under all tested conditions, and the relative abundance between them varied with the fermentation progress. On the basis of the relationships between the methanogens and fermentation parameters, it can be concluded that different microbial strains responded differently to environmental factors. The methanogens during the fermentation process were impacted by $\mathrm{pH}$ values in the presence of $\mathrm{Cd}$. After the addition of $\mathrm{Fe}$, the relationship between methanogens and $\mathrm{pH}$ was modified by the impacts of $\mathrm{Fe}$ on $\mathrm{NH}_{4}{ }^{+}-\mathrm{N}$ and acidic components. In the presence of $\mathrm{Fe}$, both Methanobrevibacter and Methanobacterium were found to be positively correlated with the daily biogas yields, suggesting that Fe impacted the biogas production by affecting the methanogens. For the $\mathrm{Cd}$ and $\mathrm{Cd}+\mathrm{Ni}$ groups, no 
methanogens were detected to be related with biogas production, which may be because of different environmental factors; further research is needed.

According to Figure 8, there was no significant correlation between methanogens and total VFA concentrations. Figure 9 shows the correlation analysis between VFA components and methanogens under different conditions. In the $\mathrm{Cd}+\mathrm{Fe}$ group, Methanothermobacter showed significant negative correlation with acetic acid $(p<0.01)$, butyric acid $(p<0.01)$, and valeric acid $(p<0.05)$. A possible reason for this result was that increases in the acetic acid, butyric acid, and valeric acid advanced acid bacteria growth, and consequently accelerated the conversion to acetic acid, followed by decreases in the activity of methanogens. These findings were consistent with the results of a previous study [53]. For the $\mathrm{Cd}$ and $\mathrm{Cd}+\mathrm{Ni}$ groups, no methanogens were detected to be related with VFA components, which may be the result of different operating conditions. Further research is needed.
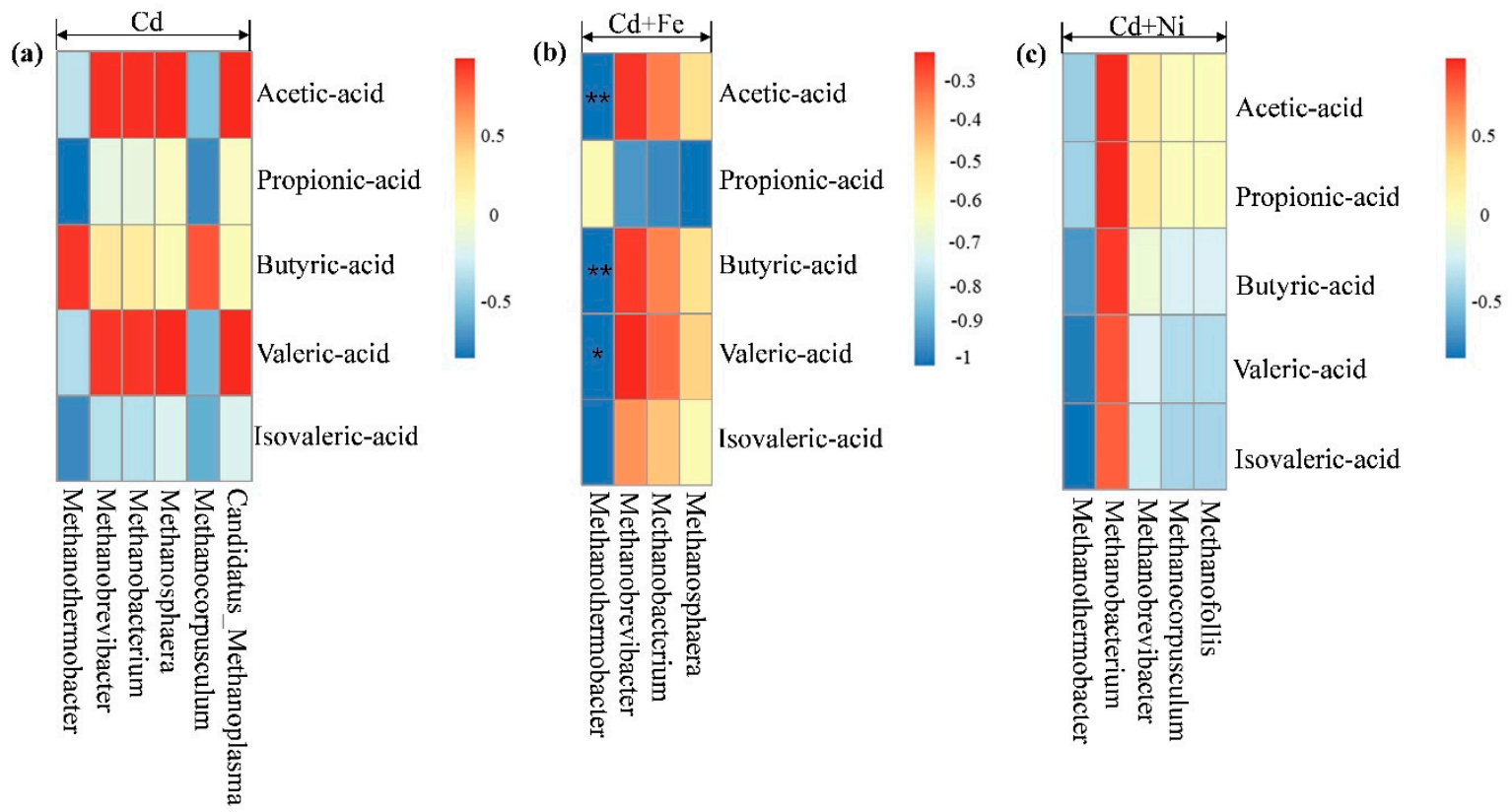

Figure 9. Pearson correlation analysis between VFA components and methanogen under $\mathrm{Cd}(\mathbf{a}), \mathrm{Cd}+$ $\mathrm{Fe}(\mathbf{b})$, and $\mathrm{Cd}+\mathrm{Ni}(\mathbf{c})$ addition during the fermentation.

\section{Conclusions}

This research studied the effects of $\mathrm{Cd}$ combined with Fe and Ni separately on anaerobic fermentation with mixed corn stover and cow manure as feedstocks. The addition of compound metals improved the biogas yields and $\mathrm{CH}_{4}$ contents remarkably. $\mathrm{Cd}+\mathrm{Fe}$ and $\mathrm{Cd}+\mathrm{Ni}$ addition led to better process stability and improved the substrate biodegradation of fermentation, which enhanced the stability of $\mathrm{NH}_{4}{ }^{+}-\mathrm{N}$ during the fermentation process and brought forward the consumption of VFA. The structure of bacterial communities and the abundance of methanogens were influenced by the addition of compound metals. Adding Fe into the Cd-containing system resulted in a different relationship between methanogens and environmental parameters, in particular $\mathrm{pH}$ values, and induced higher biogas yields. The suggestion for future research and practice is developing a mixed microbial agent for improving the degradability and $\mathrm{CH}_{4}$ yields.

Author Contributions: Conceptualization, Y.T. and H.Z.; methodology, Y.T., Y.X., and H.H. (He Hao); software, L.Z. and Y.X.; validation, all authors; formal analysis, Y.T., L.Z., and Y.X.; investigation, Y.T. and H.H. (He Hao); resources, H.Z.; data curation, Y.T. and H.H. (He Hao); writing-original draft preparation, Y.X. and Y.T.; writing-review and editing, Y.T. and H.Z.; visualization, Y.X.; supervision, H.Z. and H.H. (Hai Huang); project administration, H.Z. and H.H. (Hai Huang); funding acquisition, H.Z. and H.H. (Hai Huang). 
Funding: This work was funded by the Major Science and Technology Program for Water Pollution Control and Treatment (2017ZX07101003, 2015ZX07204007, and 2015ZX07203011); and the Fundamental Research Funds for the Central Universities (2018MS051).

Conflicts of Interest: The authors declare no conflict of interest.

\section{References}

1. Fan, S.Y.; Freedman, B.; Gao, J.X. Potential environmental benefits from increased use of bioenergy in China. Environ. Manag. 2007, 40, 504-515. [CrossRef] [PubMed]

2. Kibazohi, O.; Sangwan, R. Vegetable oil production potential from Jatropha curcas, Croton megalocarpus, Aleurites moluccana, Moringa oleifera and Pachira glabra: Assessment of renewable energy resources for bio-energy production in Africa. Biomass Bioenergy 2011, 35, 1352-1356. [CrossRef]

3. Zhuang, D.F.; Jiang, D.; Liu, L. Assessment of bioenergy potential on marginal land in China. Renew. Sustain. Energy Rev. 2011, 15, 1050-1056. [CrossRef]

4. Li, X.F.; Hou, S.L.; Su, M. Major energy plants and their potential for bioenergy development in China. Environ. Manag. 2010, 46, 579-589. [CrossRef] [PubMed]

5. Bellarby, J.; Wattenbach, M.; Tuck, G. The potential distribution of bioenergy crops in the UK under present and future climate. Biomass Bioenergy 2010, 34, 1935-1945. [CrossRef]

6. Čater, M.; Fanedl, L.; Malovrh, Š. Biogas production from brewery spent grain enhanced by bioaugmentation with hydrolytic anaerobic bacteria. Bioresour. Technol. 2015, 186, 261-269. [CrossRef]

7. Pobeheim, H.; Munk, B.; Lindorfer, H. Impact of nickel and cobalt on biogas production and process stability during semi-continuous anaerobic fermentation of a model substrate for maize silage. Water Res. 2011, 45, 781-787. [CrossRef]

8. Wei, Y.J.; Liu, Y.S. Effects of sewage sludge compost application on crops and cropland in a 3-year field study. Chemosphere 2005, 59, 1257-1265. [CrossRef]

9. Mudhoo, A.; Kumar, S. Effects of heavy metals as stress factors on anaerobic digestion processes and biogas production from biomass. Int. J. Environ. Sci. Technol. 2013, 10, 1383-1398. [CrossRef]

10. Nordell, E.; Nilsson, B.; Påledal, S.N. Co-digestion of manure and industrial waste-The effects of trace element addition. Waste Manag. 2016, 47, 21-27. [CrossRef]

11. Krishna, R.; Gilbert, W. Toxification and detoxification of heavy metals in anaerobic reactors used in the production of biohydrogen: Future fuel. Int. J. Environ. Eng. Res. 2014, 3, 1-6.

12. Li, C.L.; Fang, H. Inhibition of heavy metals on fermentative hydrogen production by granular sludge. Chemosphere 2007, 67, 668-673. [CrossRef] [PubMed]

13. Zerkle, A.L.; House, C.H.; Brantley, S.L. Biogeochemical signatures through time as inferred from whole microbial genomes. Am. J. Sci. 2005, 305, 467-502. [CrossRef]

14. Glass, J.; Orphan, V.J. Trace metal requirements for microbial enzymes involved in the production and consumption of methane and nitrous oxide. Front. Microbiol. 2012, 3, 61. [CrossRef] [PubMed]

15. Tian, Y.L.; Zhang, H.Y.; Chai, Y. Biogas properties and enzymatic analysis during anaerobic fermentation of Phragmites australis straw and cow dung: Influence of nickel chloride supplement. Biodegradation 2017, 28, 15-25. [CrossRef] [PubMed]

16. Zhang, H.Y.; Tian, Y.L.; Wang, L.J. Effect of ferrous chloride on biogas production and enzymatic activities during anaerobic fermentation of cow dung and Phragmites straw. Biodegradation 2016, 27, 69-82. [CrossRef]

17. Choong, Y.Y.; Norli, I.; Abdullah, A.Z. Impacts of trace element supplementation on the performance of anaerobic digestion process: A critical review. Bioresour. Technol. 2016, 209, 369-379. [CrossRef]

18. Ashley, N.; Davies, M.; Hurst, T.J. The effect of increased nickel ion concentrations on microbial populations in the anaerobic digestion of sewage sludge. Water Res. 1982, 16, 963-971. [CrossRef]

19. Takashima, M.; Speece, R.; Parkin, G.F. Mineral requirements for methane fermentation. Crit. Rev. Environ. Sci. Technol. 1990, 19, 465-479. [CrossRef]

20. Lin, C.Y. Effect of heavy metals on acidogenesis in anaerobic digestion. Water Res. 1993, 27, 147-152. [CrossRef]

21. Ahring, B.K. Westermann Peter. Sensitivity of thermophilic methanogenic bacteria to heavy metals. Curr. Microbiol. 1985, 12, 273-276. [CrossRef] 
22. Tsai, Y.P.; You, S.J.; Pai, T.Y. Effect of cadmium on composition and diversity of bacterial communities in activated sludges. Int. Biodeterior. Biodegrad. 2005, 55, 285-291. [CrossRef]

23. Zhang, H.Y.; Tian, Y.L.; Wang, L.J. Ecophysiological characteristics and biogas production of cadmium-contaminated crops. Bioresour. Technol. 2013, 146, 628-636. [CrossRef] [PubMed]

24. Tian, Y.; Zhang, H.; Zheng, L. Effect of Zn addition on the Cd-Containing anaerobic fermentation process: Biodegradation and microbial Communities. Int. J. Environ. Res. Public Health 2019, 16, 2998. [CrossRef]

25. Tian, Y.L.; Zhang, H.Y. Producing biogas from agricultural residues generated during phytoremediation process: Possibility, threshold, and challenges. Int. J. Green Energy 2016, 13, 1556-1563. [CrossRef]

26. Sun, W.; Qu, Y.; Yu, Q. Adsorption of organic pollutants from coking and papermaking wastewaters by bottom ash. J. Hazard. Mater. 2008, 154, 595-601. [CrossRef]

27. Wei, Y.S.; Houten, R.T.V.; Brger, A.R. Minimization of excess sludge production for biological wastewater treatment. Water Res. 2003, 37, 4453-4467. [CrossRef]

28. Allen, G.C.; Floresvergara, M.A.; Krasynanski, S. A modified protocol for rapid DNA isolation from plant tissues using cetyltrimethylammonium bromide. Nat. Protoc. 2006, 1, 2320-2325. [CrossRef]

29. Zhang, X.L.; Tian, X.Q.; Ma, L.Y. Biodiversity of the symbiotic bacteria associated with toxic marine Dinoflagellate Alexandrium tamarense. J. Biosci. Med. 2015, 3, 23-28. [CrossRef]

30. Zhang, W.; Lei, Z.; Li, A. Enhanced anaerobic digestion of food waste by trace metal elements supplementation and reduced metals dosage by green chelating agent [S, S]-EDDS via improving metals bioavailability. Water Res. 2015, 84, 266-277. [CrossRef]

31. Tang, M.; Xian, P.; Ying, X.U. Effects of $\mathrm{Fe}^{2+}, \mathrm{Co}^{2+}$ and $\mathrm{Ni}^{2+}$ on anaerobic process for landfill leachate treatment. Acta Sci. Circumstantiae 2014, 34, 2573-2579.

32. Fermoso, F.G.; Bartacek, J.; Jansen, S. Metal supplementation to UASB bioreactors: From cell-metal interactions to full-scale application. Sci. Total Environ. 2009, 407, 3652-3667. [CrossRef] [PubMed]

33. Guang, Y.; Guang, Z.; Pan, Z. Enhancement of sludge anaerobic digestion by adding trace element Fe and Ni. J. Environ. Eng.-China 2017, 11, 4971-4977.

34. Wang, K.; Yin, J.; Shen, D. Anaerobic digestion of food waste for volatile fatty acids (VFAs) production with different types of inoculum: Effect of pH. Bioresour. Technol. 2014, 161, 395-401. [CrossRef]

35. Lo, H.; Chiang, C.; Tsao, H. Effects of spiked metals on the MSW anaerobic digestion. Waste Manag. Res. 2012, 30, 32-48. [CrossRef]

36. Zhang, X.; Qiu, W.; Chen, H. Enhancing the hydrolysis and acidification of steam-exploded cornstalks by intermittent $\mathrm{pH}$ adjustment with an enriched microbial community. Bioresour. Technol. 2012, 123, 30-35. [CrossRef]

37. Mao, C.; Feng, Y.; Wang, X. Review on research achievements of biogas from anaerobic digestion. Renew. Sustain. Energy Rev. 2015, 45, 540-555. [CrossRef]

38. Lee, S.J. Relationship between Oxidation Reduction Potential (ORP) and Volatile Fatty Acid (VFA) Production in the Acid-Phase Anaerobic Digestion Process. Master's Thesis, University of Canterbury, Christchurch, New Zealand, 2008.

39. Liu, R.; Wang, Y.; Sun, C. Experimental study on biogas production from vegetable waste by anaerobic fermentation. Trans. CSAE 2008, 24, 209-213.

40. Zhang, Y.; Cañas, M.Z.; Zhu, Z. Robustness of archaeal populations in anaerobic co-digestion of dairy and poultry wastes. Bioresour. Technol. 2011, 102, 779-785. [CrossRef]

41. Sawayama, S.; Tada, C.; Tsukahara, K. Effect of ammonium addition on methanogenic community in a fluidized bed anaerobic digestion. J. Biosci. Bioeng. 2004, 97, 65-70. [CrossRef]

42. Boe, K.; Batstone, D.J.; Steyer, J.P. State indicators for monitoring the anaerobic digestion process. Water Res. 2010, 44, 5973-5980. [CrossRef] [PubMed]

43. Liu, Z.; Dang, Y.; Li, C. Inhibitory effect of high $\mathrm{NH}_{4}{ }^{+}-\mathrm{N}$ concentration on anaerobic biotreatment of fresh leachate from a municipal solid waste incineration plant. Waste Manag. 2015, 43, 188-195. [CrossRef] [PubMed]

44. Angsana, R.; Warinthom, S.; Annop, N. Combination effect of $\mathrm{pH}$ and acetate on enzymatic cellulose hydrolysis. J. Environ. Sci.-China 2009, 21, 965-970.

45. Liu, A.; Xu, S.; Lu, C. Anaerobic fermentation by aquatic product wastes and other auxiliary materials. Clean Technol. Environ. 2014, 16, 415-421. [CrossRef] 
46. Fosses, A.; Maté, M.; Franche, N. A seven-gene cluster in Ruminiclostridium cellulolyticum is essential for signalization, uptake and catabolism of the degradation products of cellulose hydrolysis. Biotechnol. Biofuels 2017, 10, 250. [CrossRef]

47. Podosokorskaya, O.; Bonch-Osmolovskaya, E.; Beskorovaynyy, A. Mobilitalea sibirica gen. nov., sp. nov., a halotolerant polysaccharide-degrading bacterium. Int. J. Syst. Evol. Microbiol. 2014, 64, 2657-2661. [CrossRef]

48. Niu, L.L.; Song, L.; Liu, X.L. Tepidimicrobium xylanilyticum sp. nov., an anaerobic xylanolytic bacterium, and emended description of the genus Tepidimicrobium. Int. J. Syst. Evol. Microbiol. 2009, 59, 2698-2701. [CrossRef]

49. Kim, B.C.; Jeon, B.S.; Kim, S. Caproiciproducens galactitolivorans gen. nov., sp. nov., a bacterium capable of producing caproic acid from galactitol, isolated from a wastewater treatment plant. Int. J. Syst. Evol. Microbiol. 2015, 65, 4902-4908. [CrossRef]

50. Maus, I.; Cibis, K.G.; Wibberg, D. Complete genome sequence of the strain Defluviitoga tunisiensis L3, isolated from a thermophilic, production-scale biogas plant. J. Biotechnol. 2015, 203, 17-18. [CrossRef] [PubMed]

51. Leahy, S.; Kelly, W.; Ronimus, R. Genome sequencing of rumen bacteria and archaea and its application to methane mitigation strategies. Animal 2013, 2, 235-243. [CrossRef]

52. Danielsson, R.; Dicksved, J.; Sun, L. Methane production in dairy cows correlates with rumen methanogenic and bacterial community structure. Front. Microbiol. 2017, 8, 226. [CrossRef] [PubMed]

53. Wang, Y.Y.; Zhang, Y.L.; Wang, J.B. Effects of volatile fatty acid concentrations on methane yield and methanogenic bacteria. Biomass Bioenergy 2009, 33, 848-853. [CrossRef]

(C) 2019 by the authors. Licensee MDPI, Basel, Switzerland. This article is an open access article distributed under the terms and conditions of the Creative Commons Attribution (CC BY) license (http://creativecommons.org/licenses/by/4.0/). 